\title{
NIH office plans research on misconduct
}

[SAN DIEGO] The Office of Research Integrity (ORI) of the US National Institutes of Health (NIH) is planning to launch a research programme to conduct studies on scientific misconduct and integrity issues. The programme is being called an invisible college', with scientists from various disciplines at different institutions independently studying misconduct.

About 15 representatives of organizations such as the National Science Foundation (NSF), the Office of the Inspector General, the NIH, the Association of American Medical Colleges and the Federation of American Societies for Experimental Biology (FASEB) attended the first planning meeting last month in Maryland.

Mary Scheetz, an information scientist at ORI's division of policy and education who helped organize the meeting, said there was strong support for scholarly studies on the topics. "There is a lack of solid research on scientific misconduct and research integrity," says Scheetz. "In order for agencies to make effective policies, they need to make decisions on solid facts. The idea is to produce a research programme to produce that data."
ORI is the lead agency addressing research misconduct occurring under $\mathrm{NIH}$ grants, but relies on institutions funded by the NIH to have policies and procedures to investigate allegations of fabrication, falsification or plagiarism.

When universities find misconduct, ORI conducts its own investigation and issues sanctions, including debarment from receiving federal funds. The NSF has similar procedures, but relies on its Office of the Inspector General to investigate.

Everyone at the meeting "agreed this is something that is important", says Rachelle Hollander, director of the NSF's program on societal dimensions of engineering, science and technology.

The federal watchdogs involved in the planning effort are keen to move beyond the image of being 'fraud police.' "We want to work with the extramural community and develop an agenda for research on misconduct," says Chris Pascal, acting director ofORI.

"We have passed the point of anecdotal evidence," added Scheetz. But she said the topics are "slippery" to study, because of the nature of the subject and the potential negative impacts for the careers of those involved. As one scientist noted: "We don't reward whistleblowers; we destroy them."

Ruth L. Fischbach, senior adviser for biomedical ethics for the NIH's director of extramural research, said she is encouraged by the idea of research on misconduct. "This is an opportunity to look at the roots and learn to be proactive to try to prevent misconduct from occurring," said Fischbach. "I have found there is a lot of secrecy within institutions about revealing the level of misconduct."

ORI is already working with a private research institution to examine academic medical centre guidelines for research staff, including authorship, retention and recording of data, and intellectual property rights. This study may lead to a scientific conference on associated issues.

At its next meeting on the misconduct research programme in November, officials hope to commission research projects before a national conference in late 2000 . The studies will be paid for initially with agency discretionary funds, officials say.

RexDalton

\section{NASA axes comet mission as delays to other projects prove costly}

[WASHINGTON] Faced with cost overruns and expensive delays to other, higher-priority science projects, the US space agency NASA has cancelled a \$240 million comet landing mission that had been proposed for early in the next decade.

The Champollion spacecraft was to have been launched in 2003 as part of NASA's 'New Millennium' programme to demonstrate advanced spacecraft technologies.

It would have met up with Comet Tempel 1 , anchored itself to the comet's nucleus and drilled for material below the surface to validate devices for use on future missions.

But Champollion was not primarily a science project and was still early in the planning stages - less than $\$ 10$ million has been spent on preliminary studies - so it became vulnerable when NASA's science office ran into financial difficulties.

Normally, the agency's $\$ 2.1$ billion science programme would be flexible enough to absorb tens of millions of dollars in unexpected costs in any given year, says Edward Weiler, head of NASA's space science office. But delays to the $\$ 1.5$ billion Chandra $\mathrm{X}$-ray observatory, resulting partly from problems with the upper-stage rocket, will add $\$ 100$ million over the next few years.

Splitting a repair of the Hubble Space Telescope into two shuttle missions, partly because of earlier slips in the schedule, added $\$ 26$ million. The $\$ 500$ million Gravity

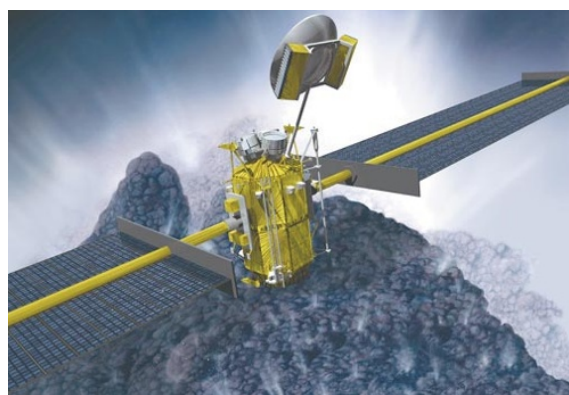

Grounded: Champollion was to have drilled under the surface of Comet Tempel 1 to collect material.

Probe-B satellite, which was scheduled to reach orbit next year, is $\$ 20$ million over budget, and NASA's Mars exploration programme was becoming low on reserves. Taken together, says Weiler, these were "not the usual year's money problems".

Champollion design work conducted at the Jet Propulsion Laboratory in California can still be applied to other missions, including an expedition to Jupiter's moon Europa. "I'm sure NASA will get around to doing a major comet mission sometime in the future," says Weiler.

For now, though, Europe's Rosetta mission, planned for launch in 2003, has that territory to itself. Champollion began life as the US contribution to Rosetta, but NASA backed out as a major partner three years ago to pursue its own comet lander as a low-cost New Millennium spacecraft (see Nature 383, 469; 1996).

US scientists will still be joint investigators on Rosetta, which will land a probe on the surface of Comet Wirtanen in 2012. Weiler says the existence of the international mission was another factor against keeping Champollion alive.

The Planetary Society, a California-based space advocacy group, was not happy with NASA's decision, and called on the US House of Representatives Science Committee to help restore money for Champollion.

In a statement, the society's director Louis Friedman said that penalizing a successful science and technology mission to pay for other programmes that are experiencing cost overruns "sets a disturbing precedent".

But NASA could not count on a Congressional rescue in a year when lawmakers are warning of a difficult appropriations battle to meet spending caps. Weiler says that cancelling Champollion "goes a long way" towards solving his impending budget problem, if Chandra launches on 20 July as planned.

The demise of the comet lander is a lesson in the difficulties of managing many "better, cheaper, faster" space missions at once. As one congressional staffer says: "There isn't the play in the NASA budget that there had been in the past."

Tony Reichhardt 